\title{
THE IMPROVISATION OF THAI XYLOPHONE OR RANAAT EEK
}

\section{Bussakorn Sumrongthong ${ }^{1}$}

Xylophones are found throughout southeast Asia, notably in Thailand, Cambodia, Indonesia, the Mon or Peguan region of southern Burma (Myanmar) and elsewhere in Burma. Thais believe (for example Yupho 1960: 12-14) that the ranaat (ระนาด) (a xylophone) evolved from the graps (กรับ), two small pieces of wood used to keep rhythm. Several graps were made and placed in a series but the notes were coarse and out of tune. They were then laid on two tracks or supports. Further improvements were made and the graps were constructed in different sizes and supported to allow the notes to resonate freely. To accomplish this, a heavy string was threaded through holes made near the ends of the graps. The graps were then placed close together and hung on a supporting stand. Two long, slender beaters with knobs at the end were used. The instrument could now be employed to play melodies. Further improvements were made to the shape of the grap, and a mixture of beeswax with lead shavings was applied to the underside of each one, permitting fine tuning and improving the tone. This original instrument was called a ranaat and the

\footnotetext{
${ }^{1}$ Assistant Professor, Music Department, Faculty of Fine And Applied Arts, Chulalongkorn University, Thailand.
}

constituent graps were named luuk ranaat (ลูกระนาด). The full series of luuk ranaat were strung on the cord, forming a continuous flat surface which was called the phunın (ผืน). The luuk ranaat were made at first of two varieties of bamboo called phai bong (ไผ่บง) and phai tong (ไผ่ตง). Later, varieties of hard wood, such as mai chingchan (ไม้ชิงชัน), mai mahaat (ไม้มหาด) and mai phayung (ไม้พยุง), were used but phai bong was always preferred because of its beautiful tone. The supporting resonator case had a shape similar to that of a Thai river boat, curving upwards at each end. This boat-shaped case was called the raang ranaat (รางระนาด). The two pieces which close each end were called the khoon (โขน), literally referring to the headpiece or prow of a boat. This boat-shaped body rested on a squat, pyramid-shaped base, the bottom of which was $22.5 \mathrm{~cm}$ (9") square with a height of $8 \mathrm{~cm}(4 ")$.

This base often had carved designs on it. In the first Thai musical ensembles only one ranaat was used, with fewer wooden bars than the modern model. Later on, another ranaat was devised to produce lower notes in order to provide the lower register. (The performing style was radically different from the first ranaat) This new model was called 
the ranaat thum (ระนาดทุ้ม) (low-pitched ranaat) and the original instrument which retained the higher notes was called the ranaat eek (ระนาดเอก)--first or principal ranaat (Figure 1 below).

The traditional ranaat eek has 21 bars. The range is shown below (Figure 2). The final note in brackets is increasingly found on modern instruments. The lowest in pitch is $38 \mathrm{~cm}$ (15") long, $5 \mathrm{~cm}$ (2") wide and 1.5 (1/2") thick. The bars decrease in size but become thicker as the pitch rises. All are hung on a cord which passes through holes at the nodes: $7.9 \mathrm{~cm}\left(2.75-3.5^{\prime \prime}\right)$ from the ends. The whole 'keyboard,' spanning about 120 $\mathrm{cm}\left(47.5^{\prime \prime}\right)$, is suspended over the boatshaped body from two metal hooks inserted into the wood at each end of the case. Some of the patterns in this thesis show the full range of the modern instrument. The majority, however, are conceived for the traditional 21-bar version. The player needs to know how to adapt the patterns which would naturally go beyond the range (at either end) of this instrument. Basically there are two options: transposition up or down one (or two) octaves; reducing the octave gap between the mallets.

It is worth noting that the range as shown in Figure 2 is a modern concept. The traditional range has the lowest note a fourth lower than its neighbour i.e. to play the lowest octave, the right mallet has to skip a fourth.

The ranaat eek player is a leader of the pii phaat (ปี่พาทย์) player - percussion ensemble, taking responsibility of performing the introduction to pieces and indicating changes of tempo. The main playing style is a regular sequence of notes in octaves, known as kep. (Example 1).

\section{Improvisation}

Improvisation - kaan praaee tamnoong (การ แปรทำนอง) in Thai music refers to the transformation of the basic melody according to the thaang (ทาง) performing way of each instrument. Improvisation in Thai music needs to be learnt and practised and is totally involved with the process of memorisation. This clearly conflicts with some Western concepts of the term: for examples, Michael Kennedy (1994: 428) writes :

Improvisation (or extemporization) is performed according to the inventive whim of the moment, i.e. without a written or printed score, and not from memory.

Robina Beckles Willson (1976: 189-190) also stated about improvisation in jazz:

As the jazzman improvised freely on the agreed harmonic basis of a tune, he not only produced cross rhythms with the other players, but also dissonant clashes.

Kennedy's definition of improvisation, which rules out memorisation, does not adequately define the meaning in Thai music in which the memory plays an essential part in the process. Although there are some kinds of harmonic basis in Thai music, Willson's mention of dissonant clashes is also inapplicable to Thai improvisation. 
Figure 1 The ranaat eek

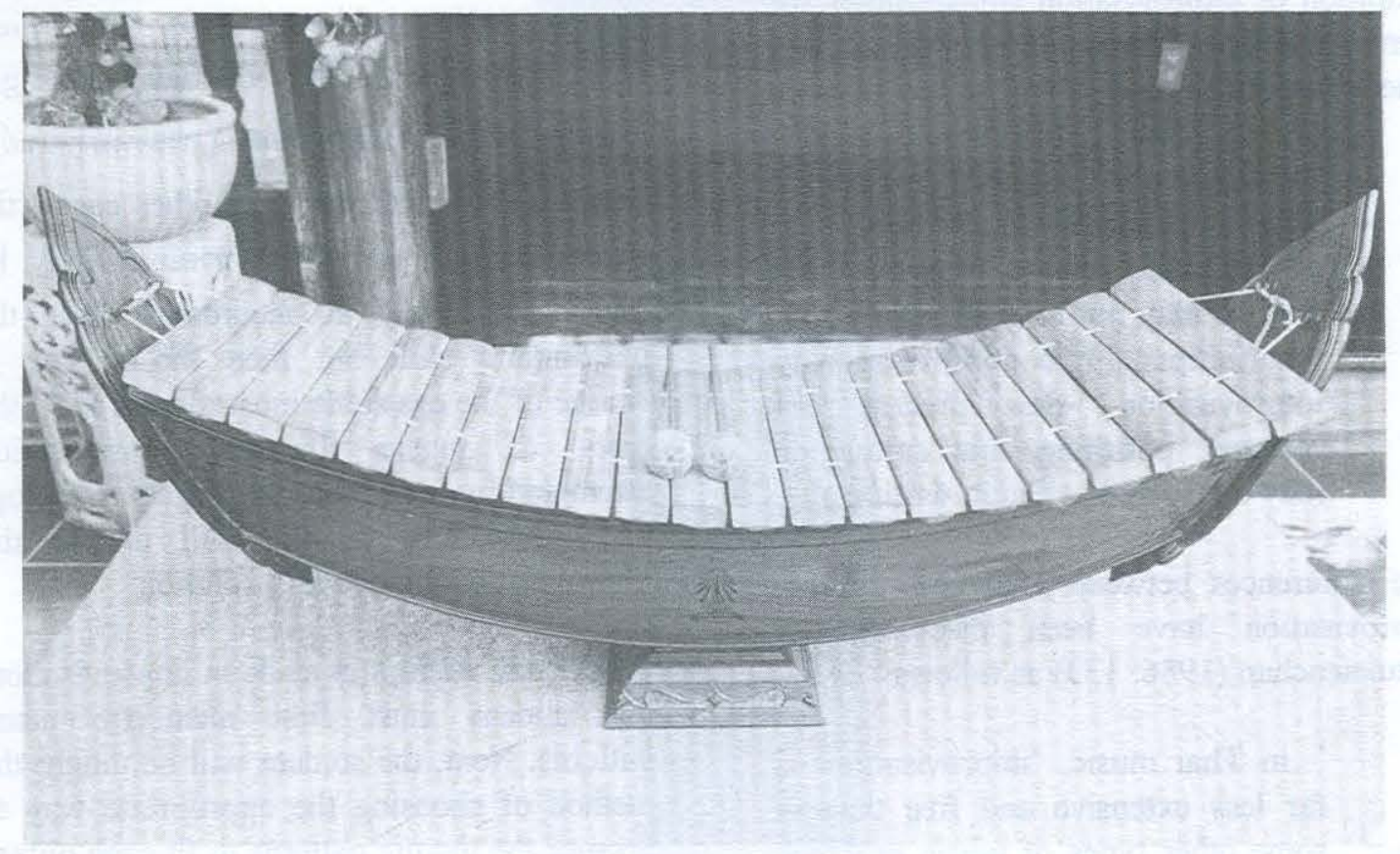

Figure 2 The range of the ranaat eek

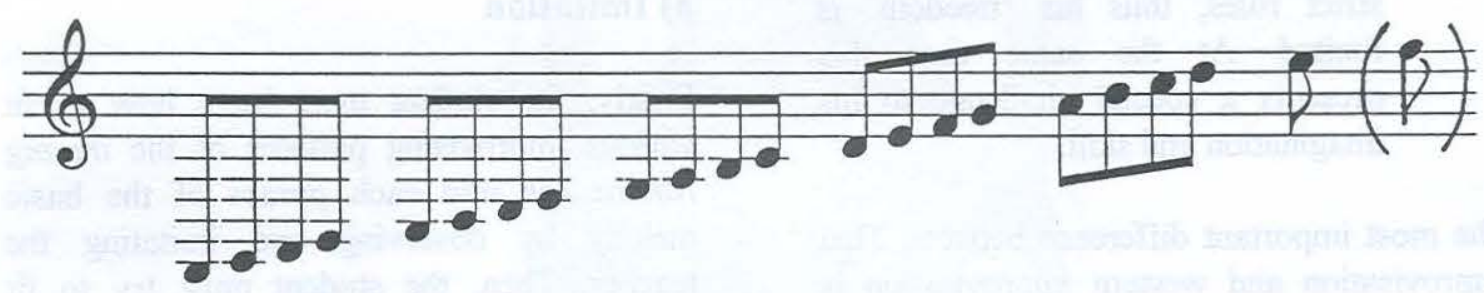

Ex.1 The kep (เก็บ) style on the ranaat eek

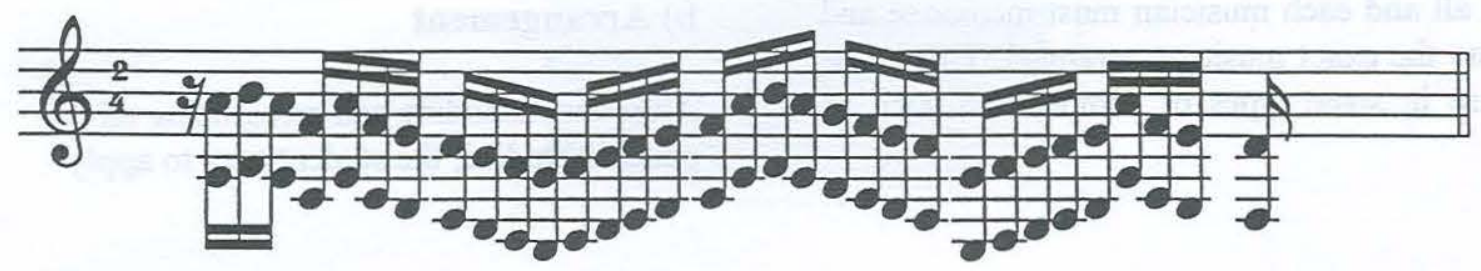


Mantle Hood (1975: 26) proposed a different definition of improvisation which allows for memorisation, both as a mental process and a kinetic (muscular) one:

Improvisation cannot proceed without reference to memory both abstract and kinetic (muscular). It may or may not refer to sketches or manuscripts. From improvisation to improvisation the process of revision, polishing, and cultivation may take place without writing.

The differences between Thai and Western improvisation have been discussed by Ketukaenchan (1986: 133) as follows:

...in Thai music, 'improvisation' is far less extensive and free than in some other types of music in which improvisation is generally recognized as having a major role to play. The Thai musician has to observe very strict rules, thus his 'freedom' is limited. At the same time this presents a special challenge to his imagination and skill.

The most important difference between Thai improvisation and western improvisation is that Thai improvisation is carefully controlled and regulated under the guidance of the director of the ensemble (the music master). Some pieces of music are arranged so that improvisation may not be carried out at all and each musician must memorise and play the exact music as arranged. This is the case in some types of composition such as the 'phleeng thaang $k r O O$ '(เพลงทางกรอ)-tremolo style, 'phleeng luuk 100 luuk khat' (เพลงลูกล้อลูกขัด) -dialogue passages and the 'phleeng naaphaat' (เพลงหน้าพาทย์) --group of sacred music. In other cases, the thaang ranaat eek (ทางระนาดเอก) may be improvised freely in accordance with the performer's skill but then the master in charge of the ensemble must always keep the unity of music. If the improvisation attempted by each musician begins to disrupt this unity, he or she will dictate the improvisational mode as a solution.

Before any attempt is made in improvisation, the student must first memorise many patterns. Next, the student will be taught the method of choosing the appropriate way to arrange the thaang patterns to fit each phrase of the piece. Improvisation on the ranaat eek can be learnt step by step as discussed below.

\section{a) Imitation}

Firstly, the student must learn how to fit various improvising patterns of the thaang ranaat eek into each phrase of the basic melody by observing and imitating the teacher. Then, the student must try to fit correctly each pattern to a phrase on his or her own; therefore through increasing experience, the greater variety of patterns evolves.

\section{b) Arrangement}

After understanding and recognizing all the patterns studied, the student tries to apply 
each pattern to fit different phrase of the basic melody, or find different patterns to the same phrase of the basic melody.

\section{c) Spontaneous decisions}

Two main kinds may be distinguished:

- applying the thaang ranaat eek which has already been learnt to the basic melody;

- creating new patterns (during the performance). This skill can be acquired through the methods of practice outline below.

\section{Tii sap (ตีสับ) following the basic melody}

The essence of learning improvisation is to proceed methodically from the very beginning. Firstly, the teacher explains the technique of tii sap: subdividing the regular notes of the main melody. The aim of this technique is to make the student familiar with the way of performing the fast regular notes which characterise the ranaat eek beating style, and to make both hands more stable before practising the real thaang ranaat eek which involves leaps. The possible simplest first step is merely to beat each note of the main melody twice. (Example 2 and 3).

\section{Development of the tii sap technique}

The basic tii sap technique is gradually transformed into something more closely resembling a real thaang ranaat eek by slight variations of a few notes. The important principle is that the change must be gradual, so that the student can fully absorb the process without rushing into complications
(Example 4 and 5).

In Example 5, the bracketed section remains very close to the basic melody, while the begianing and the end attempt a more adventurous response.

This method of simple variation is only applied to the phrase of the piece which is deemed the simplest. The remainder are left in the basic tii sap version for the time being.

\section{Extensions to the tii sap technique}

\section{- Improvising a phrase}

After understanding the way of performing the regular note-patterns of the thaang kep, the student will then start improvising phrases which involve the technique of adding notes.

The technique of adding a few notes into the tii sap technique as described earlier can be the starting point for the beginner to understand clearly the way of improvisation. This is because after practising the exercises of adding some notes, the student will become automatically used to the way of adding notes to each phrase, and then the understanding of the first level of improvisation will gradually be developed and improved.

Normally, the phrase of the basic melody is always repeated several times in each piece, hence, the more the student practises, the greater the variation of the thaang ranaat eek patterns will be discerned. The lessons of one piece, in which the student develops 
MANUSYA : Journal of Humanities Vol. 1 No. 11998

Ex. 2 Basic melody

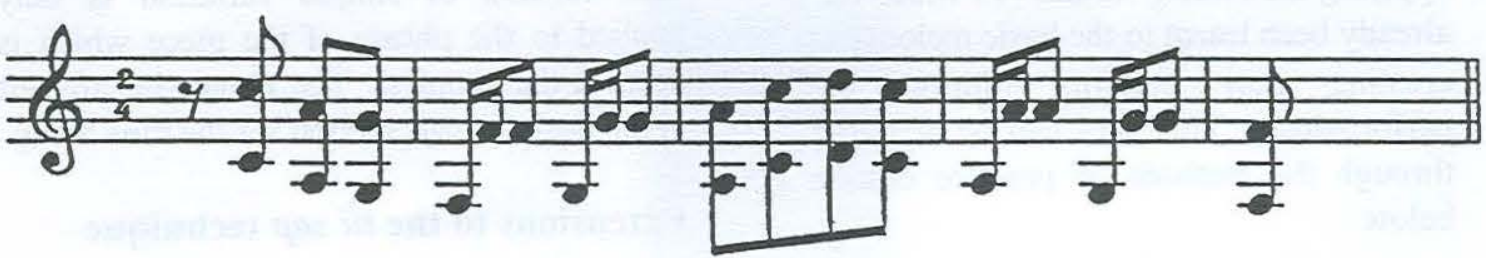

Ex. 3 Tii sap on the thaang ranaat eek

to fit Ex. 2

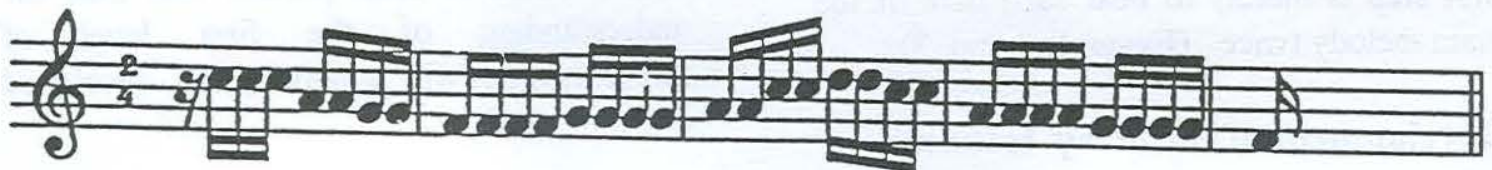


Ex. 4 Basic melody

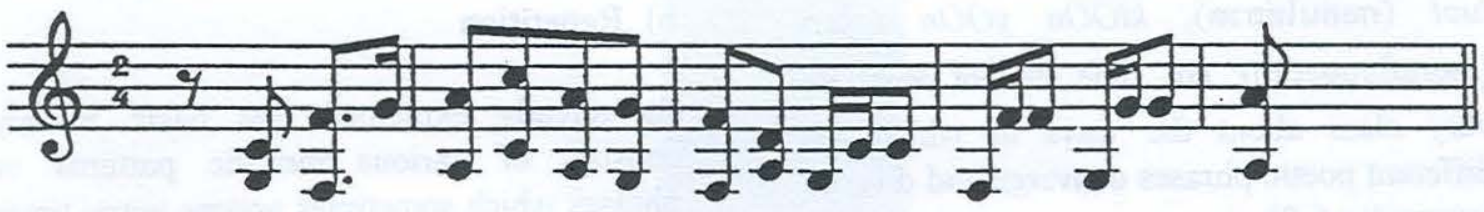

Ex. 5

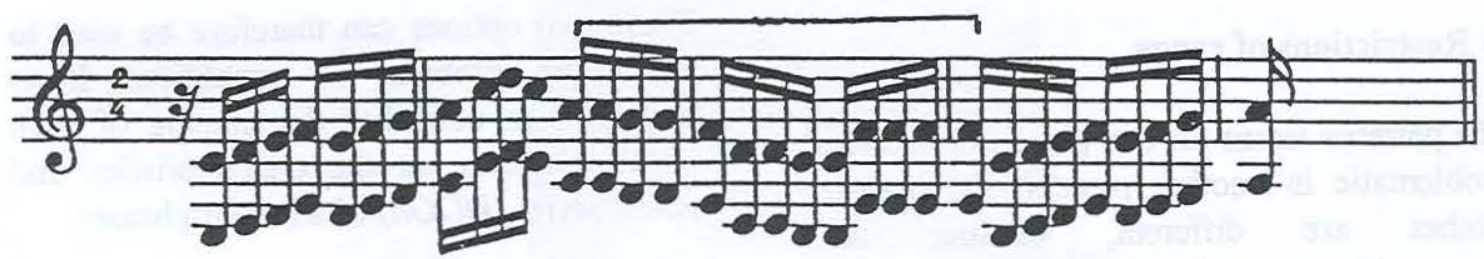


earlier exercises and imitates the example of adding notes to the tii sap technique, can be applied to another piece which uses a similar phrase.

\section{- Improvising a poetic phrase}

The patterns of improvisation constantly apply to the poetic style such as klOOn tai luot (กลอนไต่ลวด), klOOn yOOn takep (กลอนย้อนตะเข็บ), etc. The student must be very clear about the ways in which the different poetic phrases converge and diverge (examples 6-8).

Example 6 shows the shape of the $k l O O$ n tai luot which is characterised by conjunct motion, both in ascent and descent.

Example 7 and 8 share the same overall undulating characteristic, but their beginnings are different. Moreover, each klOOn has a name which describes its motion, and this assists the student to memorise its musical features.

\section{Difficulties in practising improvisation}

\section{a) Restrictions of range}

The patterns learnt for one piece can become problematic in another piece if the overall pitches are different, because the transposition can take a pattern outside the range of the instrument.

The same basic melody at different pitches, showing the adjustments necessary to keep within the range of the ranaat eek.
The transposed version of the thaang ranaat eek in Example 12 is unavailable because the notes indicated by * cannot be played on the instrıment.

A possible variant to take account of this problem would be:

\section{b) Repetition}

As already explained, the basic melody consists of various melodic patterns or phrases which sometimes appear many times in the same piece. Occasionally, a pattern can be repeated immediately; in other words, the basic melody may be played with the same phrase twice or more without any change. However, the ranaat eek must not repeat the same thaang to fit the basic melody, but must instead find variations. If two repeated phrases of thaang ranaat eek are not far apart, the repetition will create certain tedium, which should be avoided. The following examples show how the different possibilities of the thaang ranaat eek may be improvised to fit identical basic melodies.

These two options can therefore be used to avoid the problem of repetition. It is important to note that the placing of each phrase depends on the characteristics and poetic styles $(\mathrm{klOOn})$ of adjacent phrases.

There are other interesting methods of Thai improvisation which are not discussed in this article. Those interested can get more information via e-mail:

sbussako@pioneer.netserv.chula.ac.th URL:http://www.pioneer.netserv.chula.ac.th/ $\sim$ sbussako 
Ex. 6 KlOOn tai lout (กลอนไต่ลวด)

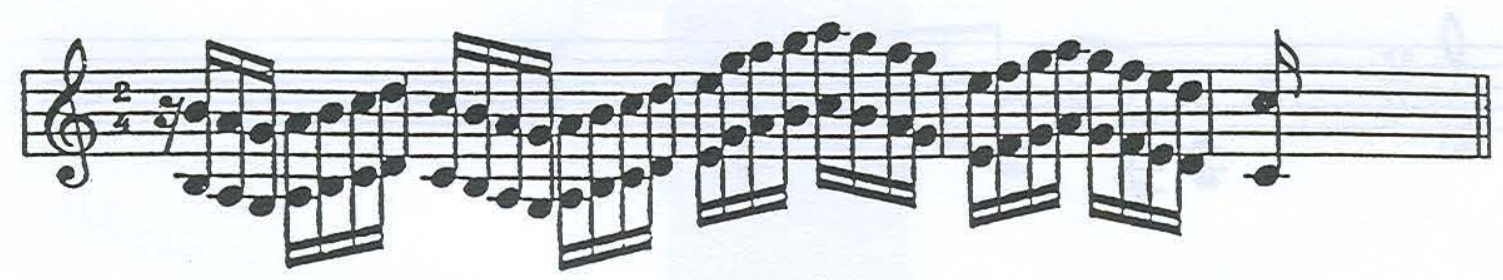

Ex. 7 KlOOn yoon takep (กลอนย้อนตะเข็บ)

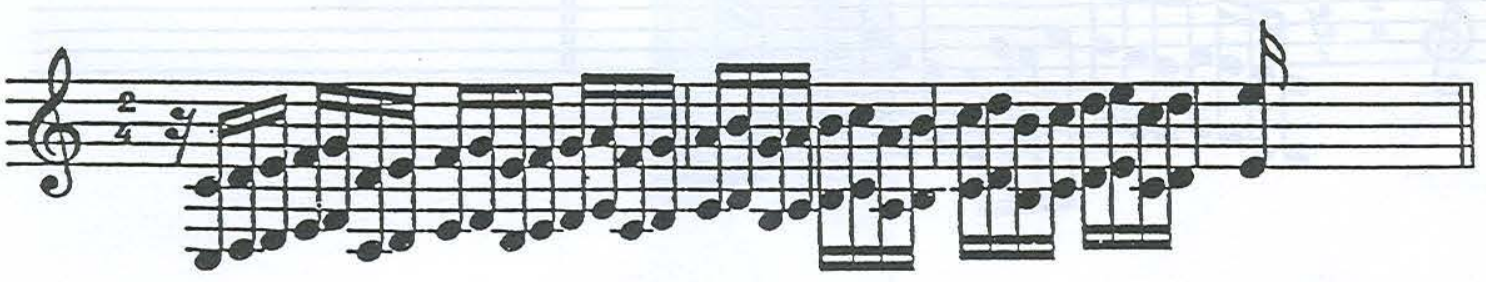

Ex. 8 KlOOn doen takep (กลอนเดินตะเข็บ)

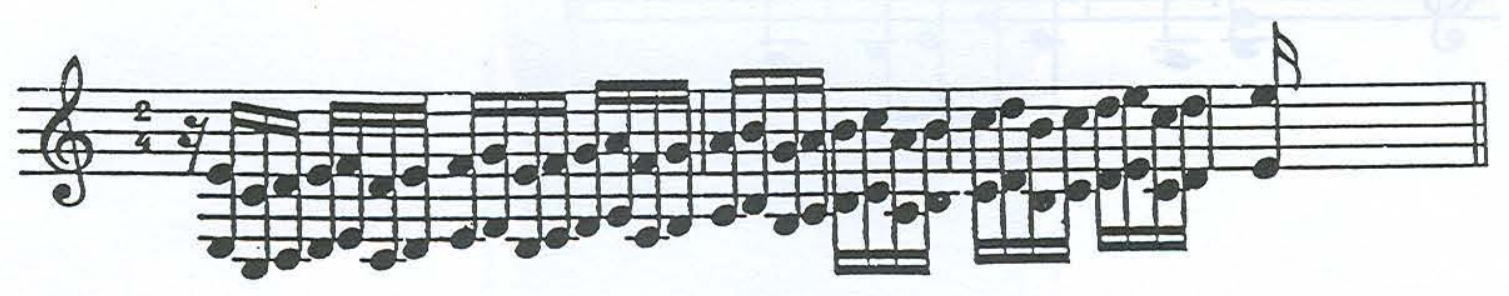


Ex. 9 Basic melody

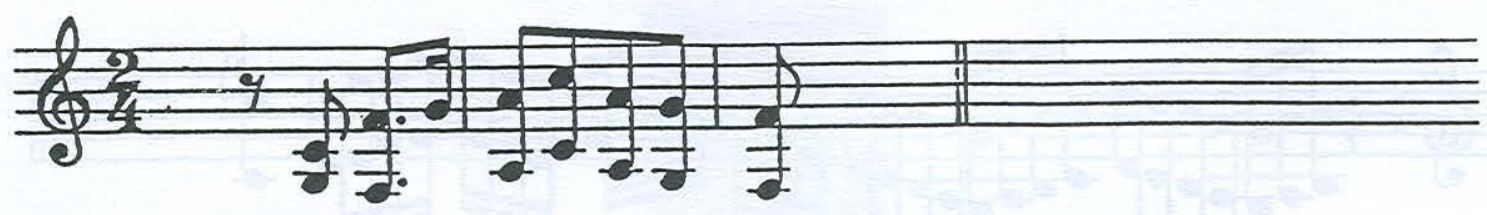

Ex.10 The thaang ranaat eek to fit this could be

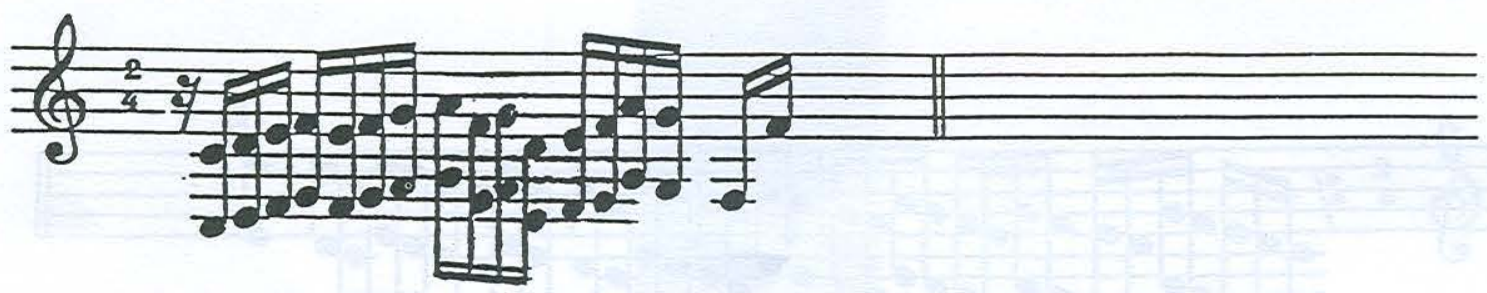

Ex.11 Basic melody, transposed upwards

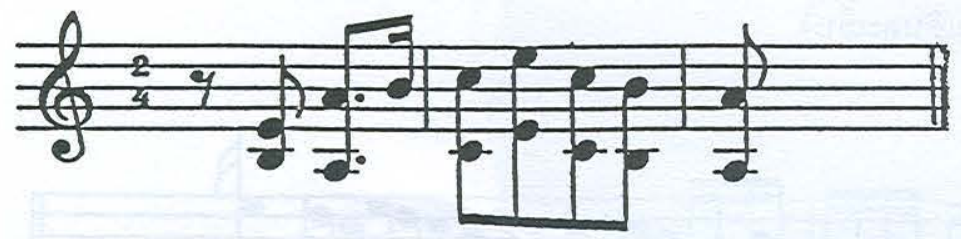




\section{Ex.12}

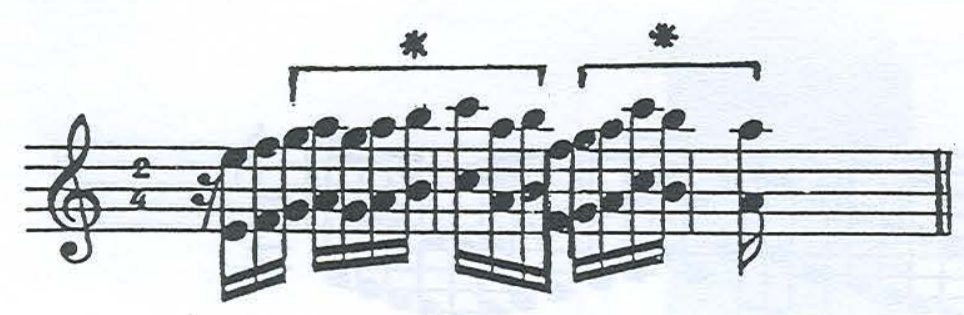

Ex.13

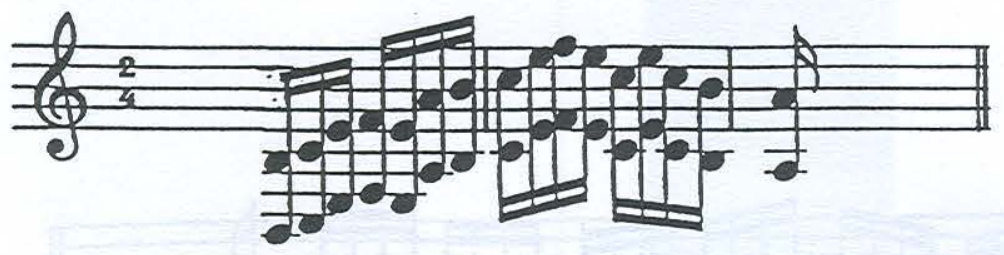

Ex.14 The same phrase repeated

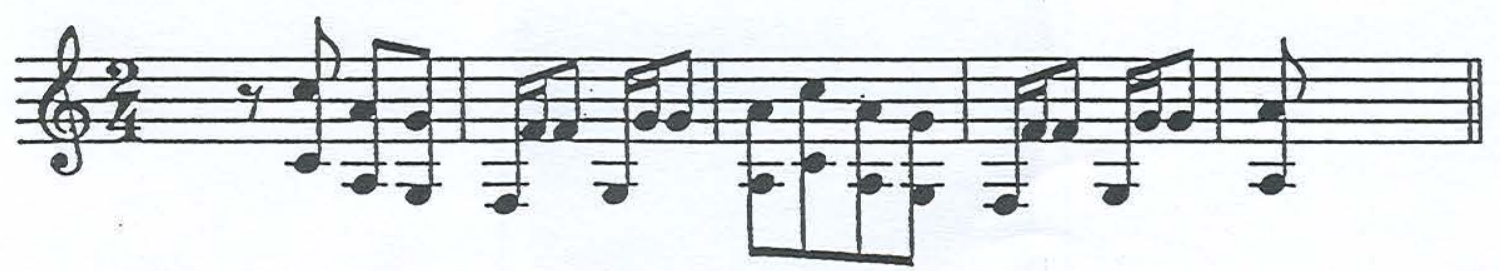


MANUSYA : Journal of Humanities Vol. 1 No. 11998

Ex.15 Possibility 1

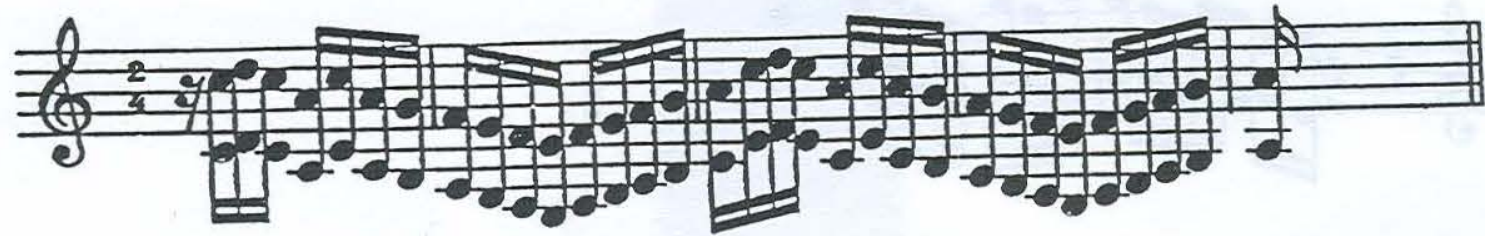

Ex.16 Possibility 2

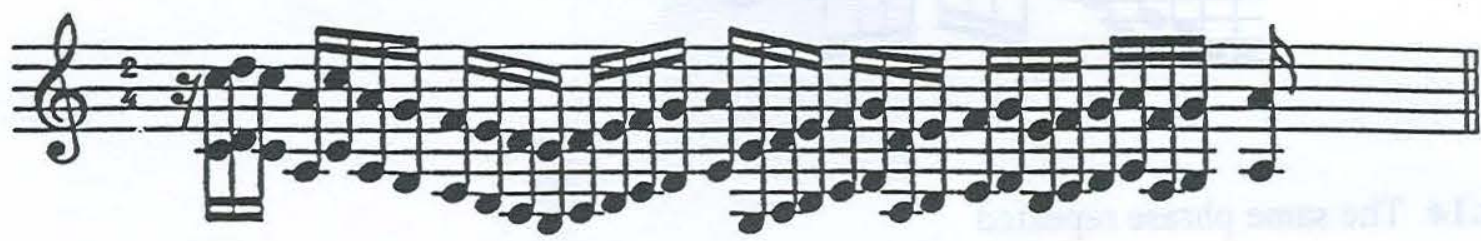




\section{Glossary of the important Thai terms}

$\begin{array}{ll}\text { grap (กรับ) } & \text { wooden clappers } \\ \text { kep (เก็บ) } & \begin{array}{l}\text { regular stream of fast notes } \\ \text { played in octaves on the } \\ \text { ranaat eek }\end{array} \\ \text { khoon (โขน) } & \begin{array}{l}\text { the two pieces which close } \\ \text { ach end of the raang ranaat }\end{array} \\ \text { klOOn (กลอน) } & \text { phrases played against the } \\ & \text { basic melody, arranged in } \\ & \text { symmetrically balanced } \\ & \text { phrases (poetic style). } \\ & \text { Most } k l O O n \text { for the ranaat } \\ & \text { eek now have names, but } \\ \text { some others have not yet } & \text { been named. }\end{array}$

$k l O O n$ doen takhep (กลอนเดินตะเข็บ) $k l O O n$ with sequential repetition of the initial fournote motif

klOOn tai luot (กลอนไต่ลวด)

klOOn characterised by conjunct motion

$k l O O n$ yOOn takhep (กลอนย้อนตะเข็บ) klOOn in which the pattern is similar to that of $\mathrm{klOOn}$ doen takhep but in a different shape

$k r O O$ (กรอ) the technique of playing sustained notes by means of tremolo

luuk ranaat (ลูกระนาด) bar of the ranaat mai (ไม้) wood phleeng (เพลง) a piece/composition

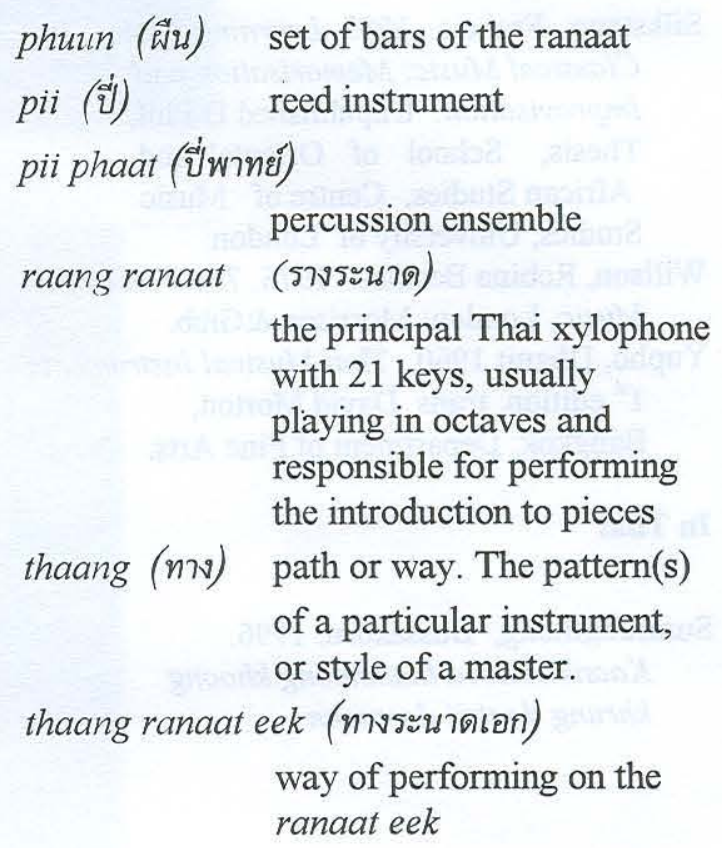

thaang ranaat eek (ทางระนาดเอก) way of performing on the ranaat eek

\section{References}

\section{In English}

Duriyanga, Chen, Phra. 1948. Siamese Music in Theory and Practice as Compared with that of the West and a Description of the Piphat. Bangkok: Department of Fine Arts.

Hood, Mantle. 1975. Improvisation in the Stratified Ensembles of S.E. Asia, Selected Readings in Ethnomusicology 2:25-33.

Kennedy, Michael. 1994. The Oxford Dictionary of Music, Oxford: Oxford University Press.

Ketukaenchan, Somsak. 1989. The thang of the khong wong yai and ranat ek: a Transcription and Analysis of Performance Practice in Thai Music. Unpublished D Phil.Thesis, University of York. 
Silkstone, Francis. 1993. Learning Thai Classical Music: Memorisation and Improvisation. Unpublished D Phil. Thesis, School of Oriental and African Studies, Centre of Music Studies, University of London.

Willson, Robina Beckles. 1976. The Voice of Music, London: Morrison \&Gibb.

Yupho, Dhanit 1960. Thai Musical Instruments $1^{\text {st }}$ edition, trans. David Morton, Bangkok: Department of Fine Arts. thamnoong prapheet khrueng tii [Improvisation in Thai melodic percussion] Bangkok: Chulalongkorn University Press.

Thavorn, Prasit. 1979. 'Luk sip prakarn' [Ten Principles], in Dontrii Thai Udomsuksa [Thai music in University] no.8., Bangkok: Ramkhumhaeng University.

Tramote, Montri. 1964. Sap sangkhiit [Dictionary of Thai musical terms], Bangkok: Department of Fine Arts.

\section{In Thai}

Sumrongthong, Bussakorn. 1996. Kaankamnoed thamnoong khoong khrung dontrii damnoen 